\title{
Effect of selenium foliar application on oil yield, fatty acid composition and glucosinolate content of rapeseed cultivars under late-season thermal stress ${ }^{\text {th }}$
}

\author{
Abdoreza Davoudi ${ }^{1}$, Bahram Mirshekari ${ }^{1, *}$, Amirhosein Shirani-Rad ${ }^{2}$, Farhad Farahvash ${ }^{1}$ and \\ Varahram Rashidi ${ }^{1}$ \\ ${ }^{1}$ Department of Agronomy and Plant Breeding, Islamic Azad University, Tabriz Branch, Iran \\ 2 Seed and Plant Improvement Institute (SPII), Agricultural Research, Education and Extension Organization (AREEO), Karaj, Iran
}

Received 7 March 2019 - Accepted 7 June 2019

\begin{abstract}
To determine the possible protective and enhancer role of selenium foliar application on oil yield, fatty acid composition and glucosinolate content of rapeseed cultivars under late-season thermal stress, a factorial split-plot experiment based on randomized complete block design with three replications was carried out in Karaj, Iran during the two growing seasons 2014-2015 and 2015-2016. Three sowing dates (Oct. 7 as normal planting date), (Oct. 17 as semi-late planting date), (Oct. 27 as late planting date) and two selenium foliar application (non-application as control and sodium selenate as foliar application) were factorially randomized to main plots, and rapeseed cultivars were allocated to sub-plots. Plant materials were six cultivars including three hybrids and three Iranian open pollinated varieties. Lateseason thermal stress caused by late planting date reduced oil yield, oil content, oleic acid, linoleic acid, palmitic acid and increased linolenic acid, erucic acid and glucosinolate content of investigated cultivars. The results of this study demonstrated that the highest amount of oil yield, oil content, oleic acid, linoleic acid, palmitic acid and the lowest amount of erucic acid and glucosinolate content were observed in L72 cultivar in both control and selenium application treatments. This study provided new important findings about the supportive and enhancer role of selenium in the form of sodium selenate on quantity and quality of oil in rapeseed plant.
\end{abstract}

Keywords: canola / linoleic acid / oil quality / sodium selenate / sowing date

Résumé - Effet de l'application foliaire de sélénium sur le rendement en huile, la composition en acides gras et les teneurs en glucosinolates de cultivars de colza en situation de stress thermique de fin de saison. Afin d'étudier le possible effet protecteur et fortifiant de l'application foliaire de sélénium sur le rendement en huile, la composition en acides gras et les teneurs en glucosinolates de cultivars de colza en situation de stress thermique de fin de saison, un plan d'expériences factoriel en parcelles divisées selon un plan en blocs aléatoires complets avec 3 répétitions a été réalisé à Karaj, en Iran, pendant les deux saisons de culture 2014-2015 et 2015-2016. Trois dates de semis (le 7 octobre, comme date de plantation normale, le 17 octobre comme date de plantation semi-tardive et le 27 octobre comme date de plantation tardive) et deux modalités d'application foliaire de sélénium (non application en tant que témoin et sélénate de sélénium pour l'application foliaire) ont été aléatoirement attribuées aux principales parcelles selon le plan factoriel. Les cultivars de colza ont été répartis sur les sousparcelles. Parmi les six cultivars, trois étaient des hybrides et trois des variétés à pollinisation libre. Le stress thermique de fin de saison dû à la date de plantation tardive a entraîné une diminution du rendement en huile, de la teneur en huile, des teneurs en acides oléique, linoléique, et palmitique et une augmentation des teneurs en acides linolénique, érucique et en glucosinolates dans les cultivars

\footnotetext{
Contribution to the Topical Issue "Rapeseed / Colza".

*Correspondence: mirshekari@iaut.ac.ir
} 
analysés. Le rendement et les teneurs les plus élevés en huile, acide oléique, linoléique, palmitique et les teneurs les plus faibles en acide érucique et en glucosinolates étaient obtenus pour le cultivar L72, aussi bien en cas d'application foliaire de sélénium qu'en son absence. Cette étude apporte de nouveaux résultats importants à propos de l'effet stimulant et fortifiant du sélénium sous forme de sélénate de sodium sur la quantité et la qualité de l'huile de colza.

Mots clés : colza / acide linoléique / qualité de l'huile / sélénate de sodium / date de semis

\section{Introduction}

Rapeseed (Brassica napus L.) is one of the most important oilseeds in the world that is considered as the third provider of edible oil after oil palm and soybean. With the lowest content of saturated fatty acids, rapeseed is one of the most important sources of vegetable oils for human diet (Nelson and Grombacher, 1992), industrial and pharmaceutical consumptions (Carvalho et al., 2006).

Rapeseed is a long-day plant that grows well if it is sown on an appropriate sowing date (Shirani-Rad et al., 2015a). Therefore, following proper agronomic practices, including setting a suitable sowing date, will help increase yield and produce high-quality oil (Shirani-Rad et al., 2015b). Planting date is one of the main factors in rapeseed production affecting crop yield and other agronomic traits. Most previous studies have revealed that late planting date results in low yields (Hocking and Stapper, 2001; Oz, 2002; Ozer, 2003; Shah and Rahman, 2009; Uzun and Furat, 2009; Singh et al., 2017).

Plants are exposed to various types of biotic and abiotic stresses during their growth period, which reduce their yield production (Kumar, 2013). Rapeseed oil production is negatively influenced by late-season thermal stress and low precipitation and positively affected by above-average precipitation and below-average lower temperatures (Kutcher et al., 2010). Maximum daily temperatures greater than $27^{\circ} \mathrm{C}$, which usually occurs in rapeseed growing areas, can reduce flower number, the number of pods per plant and consequently seed yield losses due to heat stress (Morrison and Stewart, 2002).

Selenium (Se) as a naturally occurring chemical element, which was long known as a toxic substance before its usefulness, was identified by Schwarz and Foltz (1957). Only in the last decades, its physiological importance as a micronutrient fundamental to animal and human health has been assessed (Mora et al., 2015). Selenium is known to reduce abiotic stresses, which have been extensively studied in animals and less in humans and plants (Feng et al., 2013).

The first report of positive effect of selenium application in the form of selenite on growth and dry-matter yield of Indian mustard (Brassica juncea L.) was presented by M. Singh et al. (1980). Lack of selenium concentration in the soil causes its deficiency in the human diet. Recently, sodium selenate has been used as a fertilizer for foliar application in order to increase selenium content in the edible portion of crops (Broadley et al., 2010; Pezzarossa et al., 2012) and simultaneously to deal with the damage caused by various environmental stresses (Saidi et al., 2014).

Application of selenium as a foliar fertilizer has been reported for soybean (Yang et al., 2003; Djanaguiraman et al., 2005), green tea (Hu et al., 2003), lettuce (Xue et al., 2001), ryegrass (Hartikainen et al., 2000), chicory (Germ et al., 2007), wheat (Stephen et al., 1989; Ducsay and Lozek, 2006; Yao et al., 2013; Nawaz et al., 2015), barley (Gissel Nielsen, 1981; Ylaranta, 1983), rice (Hu et al., 2002; Fang et al., 2008), potato (Poggi et al., 2000) and corn (Sajedi et al., 2011). The effect of selenium application via solution culture was reported to increase growth and seed production of Brassica plants (Lyons et al., 2009).

The protective role of selenium in delayed planting of rapeseed under salt stress was observed in the study of (Hashem et al., 2013), in which Se increased plant growth, seed yield, photosynthetic pigments content and improved the quality of rapeseed oil. Selenium application can improve plant growth (Pilon-Smits et al., 2009), increase tolerance against biotic and abiotic stresses (Hartikainen et al., 2000, Hartikainen, 2005) and improve other physiologic parameters (Xue et al., 2001; Djanaguiraman et al., 2005; Turakainen et al., 2006).

The quality and quantity of oil in oilseed crops are associated with fatty acid composition, mainly with percentage of unsaturated linoleic and oleic acids, and other saturated fatty acids. Some stresses including temperature and sowing date of rapeseed may affect fatty acid composition of the crop (Izquierdo et al., 2006).

This study aimed to determine the possible protective and enhancer role of selenium foliar application on oil yield, fatty acid composition and glucosinolate content of rapeseed cultivars under late-season thermal stress.

\section{Materials and methods}

\subsection{Site description and soil type}

This study was carried out at an experimental field of Seed and Plant Improvement Institute, Karaj, Iran $\left(\mathrm{N} 35^{\circ} 49^{\prime} \mathrm{E} 51^{\circ} 6^{\prime}\right.$, elevation $\left.=1321 \mathrm{~m}\right)$ during the two growing seasons 2014-2015 and 2015-2016. According to IRIMO data (IRIMO, 2016), this location has a semi-arid climate (243 $\mathrm{mm}$ mean annual rainfall over the past 30 years, mainly in late fall and early spring). Meteorological data of the experimental location in two growing seasons are shown in Table 1.

The soil texture in the experimental field was clay-loam, low in organic matter and alkaline in reaction. Basic soil chemical properties of experimental field are presented in Table 2.

\subsection{Experimental design}

This study was performed in a factorial split-plot experiment based on randomized complete block design with three replications. Three sowing dates (Oct. 7 as normal 
Table 1. Meteorological data of experimental location in two growing seasons (2014-2016).

\begin{tabular}{|c|c|c|c|c|c|c|c|c|c|c|}
\hline$\frac{\text { Month }}{\text { Year }}$ & \multicolumn{2}{|c|}{ October } & \multicolumn{2}{|c|}{ November } & \multicolumn{2}{|c|}{ December } & \multicolumn{2}{|c|}{ January } & \multicolumn{2}{|c|}{ February } \\
\hline Rainfall (mm) & 5 & 22.2 & 31.4 & 57 & 22.8 & 27.9 & 2.9 & 14.7 & 24.7 & 11.2 \\
\hline Month & \multicolumn{2}{|c|}{ March } & \multicolumn{2}{|c|}{ April } & \multicolumn{2}{|c|}{ May } & \multicolumn{2}{|c|}{ June } & \multicolumn{2}{|c|}{ July } \\
\hline Mean temp. $\left({ }^{\circ} \mathrm{C}\right)$ & 9.3 & 11.3 & 16.7 & 14.8 & 22 & 21.3 & 28.1 & 25.6 & 28.9 & 27.6 \\
\hline
\end{tabular}

Table 2. Soil charactristics of experimental field.

\begin{tabular}{llllllll}
\hline Soil texture & Soil depth $(\mathrm{cm})$ & $\mathrm{EC}(\mathrm{ds} / \mathrm{m})$ & $\mathrm{pH}$ & Organic carbon $(\%)$ & Phosphorus $(\mathrm{mg} / \mathrm{kg})$ & Potassium $(\mathrm{mg} / \mathrm{kg})$ & $\mathrm{Nitrogen}(\%)$ \\
\hline \multirow{2}{*}{ Clay-loam } & $0-30$ & 1.45 & 7.9 & 0.91 & 14.7 & 197 & 0.09 \\
& $30-60$ & 1.24 & 7.2 & 0.99 & 15.8 & 155 & 0.07 \\
\hline
\end{tabular}

Table 3. Description of rapeseed genotypes used in the experiment.

\begin{tabular}{llll}
\hline No. & Cultivar name & Type & Origin \\
\hline 1 & Opera & Open pollinated & Sweden \\
2 & L72 & Open pollinated & Iran \\
3 & KR1 & Open pollinated & Iran \\
4 & GKH3705 & Hybrid & Hungary \\
5 & GKH0224 & Hybrid & Hungary \\
6 & Neptune & Hybrid & France \\
\hline
\end{tabular}

planting date), (Oct. 17 as semi-late planting date), (Oct. 27 as late planting date) and two selenium foliar application (nonapplication as control and sodium selenate as foliar application) were factorially randomized to main plots, and rapeseed cultivars were allocated to sub-plots. Plant materials were six cultivars including three hybrids and three Iranian open pollinated varieties, which were described in Table 3 .

\subsection{Experimental procedure}

Each experimental plot consisted of six $6 \mathrm{~m}$ lines with $30 \mathrm{~cm}$ space between the lines and $4 \mathrm{~cm}$ between plants. Hence, the required area for each plot was $10.8 \mathrm{~m}^{2}$. Two lateral lines were considered as margins. Phosphorus, nitrogen, and potassium were applied according to the recommendations of soil analysis before and after sowing at a rate of 70, 50, and $100 \mathrm{~kg} / \mathrm{ha}$ in the form of ammonium phosphate, urea, and potassium sulfate, respectively. Irrigations were done based on the water needs of plants. To apply the Se treatment, $30 \mathrm{~g} / \mathrm{L} / \mathrm{ha}$ sodium selenate was sprayed as foliar application and pure water for non-application were used as control before the rosette stage (early December) as described by Seppänen et al. (2010). Urea fertilization was applied equally at stem elongation and heading stages at the rate of $50 \mathrm{~kg} / \mathrm{ha}$. Plants were thinned by hand at the 6-leaf stage. To minimize seed shattering, each experimental plot was harvested in different dates before the seed is fully mature.

\subsection{Measurement of oil content, oil yield and fatty acid composition}

Measurement of oil content were performed by $5 \mathrm{~g}$ seed sample which selected from each plot using NMR (Nuclear Magnetic Resonance) German Broker Brand minispec mq20 Model based on the International Standard (ISO-5511:1992, 1998). Then, oil yield was calculated by multiplying oil content in seed yield. Fatty acid composition of oils was analyzed using gas chromatography (GC) as described by Aksouh et al. (2001). The glucosinolate content of seed samples was determined as described by Makkar et al. (2007).

\subsection{Statistical analysis}

Outlier detection and testing the normality of the data were done before variance analysis. Then, homogeneity of variance assumption was performed using Bartlett's test. Differences among treatments were analyzed by ANOVA and then compared using the least significant difference test (LSD) at 0.05 level of probability. Interactions were interpreted using slicing procedure by SAS 9.1 (SAS, 2008) statistical software. Excel software used for graphs.

\section{Results and discussion}

The main effects of year, planting date, selenium application and cultivar on all investigated traits were significant (Tab. 4). The interaction effect of cultivar $\times$ planting date was significant on all traits except for oleic and erucic acids (Tab. 4). The interaction effect of planting date $\times$ selenium $\times$ cultivar was significant on oil yield, oleic 
Table 4. Analysis of variance and comparison of main effects for oil yield, oil content and fatty acid composition of rapeseed cultivars under late-season thermal stress and selenium foliar application.

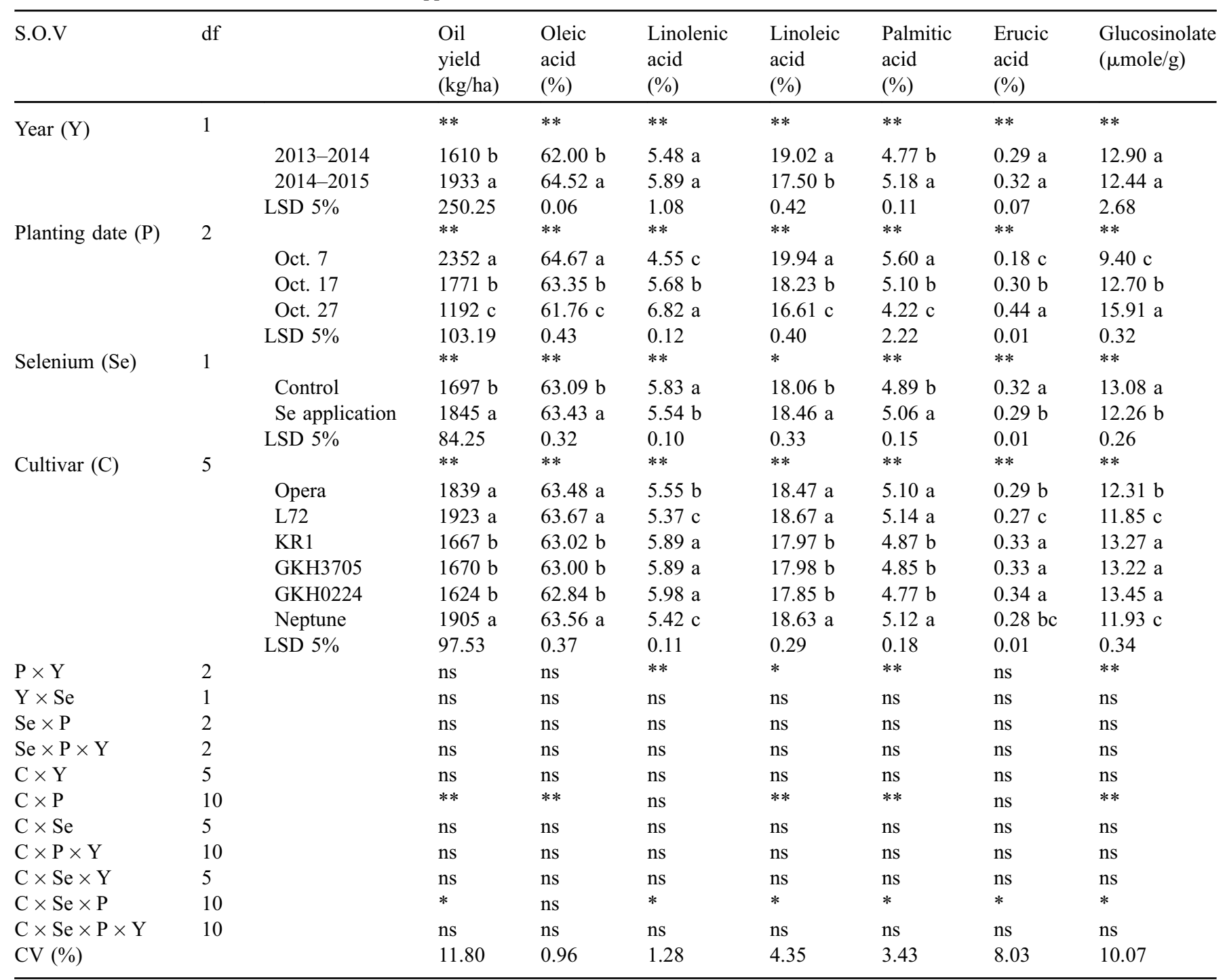

*: Significant at 5\% level of probability; **: Significant at 1\% level of probability; S.O.V.: Source of variation; df: Degree of freedom; CV: Coefficient of variation; Y: Year; R: Replication; P: Planting date; Se: Selenium; C: Cultivar.

$\mathrm{a}-\mathrm{c}$ : Means followed by similar letters in each column are not significant at 0.05 probability level.

acid, linolenic acid, linoleic acid, palmitic acid, erucic acid and glucosinolate content (Tab. 4).

\subsection{Oil content and yield oil}

Response of cultivars to year, planting date and selenium application in terms of oil yield and oil content was statistically significant (Tab. 4). The interaction effect of planting date $\times$ selenium $\times$ cultivar was significant on oil yield but nonsignificant for oil content (Tab. 4).

The highest oil content were observed in 2015-2016 growing year (42.31\%), normal planting date (Oct. 7) $(43.43 \%)$ and selenium application treatment $(42.30 \%)$ (Figs. 1-3). L72 cultivar with the average of $42.49 \%$ had the highest oil content among cultivars. In addition, there were no significant differences between Opera and Neptune with L72 cultivars (Fig. 4).

Higher amounts of oil content, the highest oil yield was obtained in the second year of the experiment can be attributed to more rainfall and a lower mean temperature than the first year, especially at seed filling period in critical months April and May (Tab. 1). Fayyaz-Ul-Hassan et al. (2005) concluded that lower late-season temperatures are suitable for good quality of oil in crops. Results of present study were in accordance with Pritchard et al. (2000) and Omidi et al. (2010) studies who found that oil content of cultivars are associated with cooler temperature and higher spring rainfall. This shows that the normal planting is superior to delayed planting in terms of selenium application That is because the longer vegetative period and the optimal use of selenium spray application. 
Oil content $(\%)$

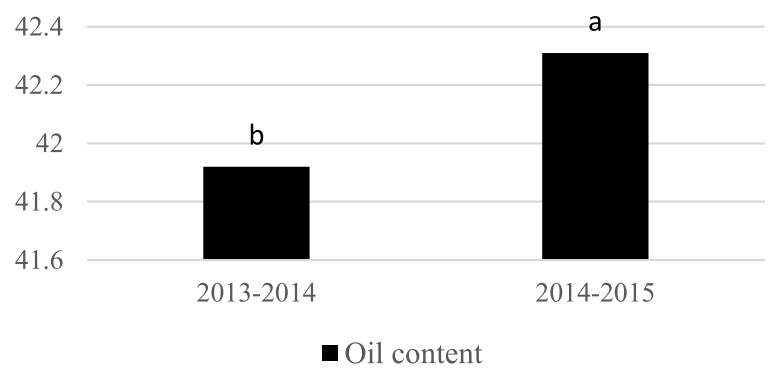

Fig. 1. Mean comparison of main effect of year on oil content.

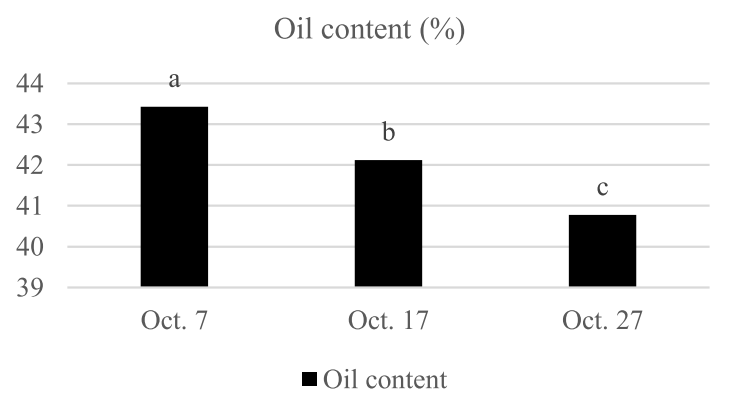

Fig. 2. Mean comparison of main effect of planting date on oil content.

Sinaki et al. (2007) reported that seed and oil yield of canola cultivars were increased with increasing the moisture content after pollination phase. Water stress in different stages of canola especially at end of the season reduced seed oil yield (Soleymani et al., 2011). The average oil content was higher in normal planting date (Oct. 7) compare to semi-late (Oct. 17) and late (Oct. 27) planting dates under controlled conditions (Fig. 2). It seems that late planting dates cause shorter growth period for rapeseed. Therefore, the less growth period, the more reduce in oil content. However, delay in planting, due to plant growth retardation, exposure to thermal stress during the seed filling stage at the end of the season (Gilbertson et al., 2007), increased respiration and decreased photosynthesis efficiency (Seppänen et al., 2003), resulting in a decrease in the seed oil content, compared to the normal planting date. In addition, the average oil content was higher in selenium foliar application than control (Fig. 3). Therefore, application of selenium increased the oil content. Similar to oil content, highest oil yield was obtained in the second year of the experiment $(1933 \mathrm{~kg} / \mathrm{ha})$ and normal planting date $(2352 \mathrm{~kg} /$ ha). Selenium application treatment increase oil yield from 1697 to $1845 \mathrm{~kg} / \mathrm{ha}$ in all planting dates of the experiment (Tab. 4). Lyons et al. (2009) reported that Se treatment showed a $43 \%$ increase in seed yield of Brassica plants. L72 cultivar with the average of $2630 \mathrm{~kg} / \mathrm{ha}$ in normal planting date (Oct. 7) and selenium application had the highest amount of oil yield, while in semi-late planting date (Oct. 17) and delayed planting date (Oct. 27) the highest amount of oil yield was related to Opera cultivar (Tab. 4). Generally, in rapeseed, oil content is mainly determined by genetic factors rather than environmen-
Oil content $(\%)$

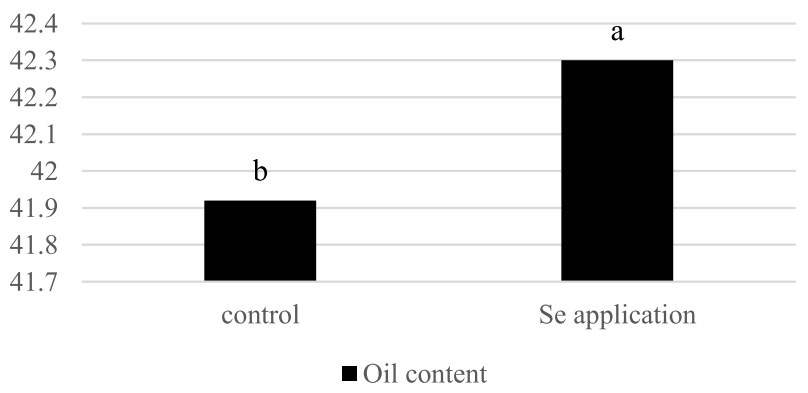

Fig. 3. Mean comparison of main effect of selenium on oil content.

Oil content $(\%)$

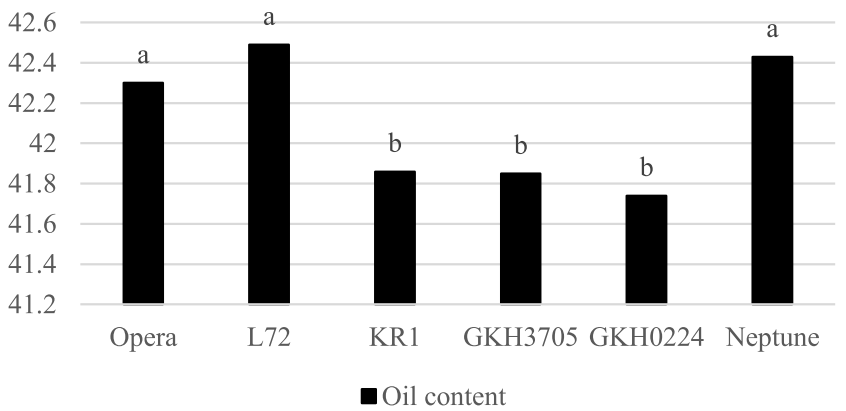

Fig. 4. Mean comparison of main effect of cultivar on oil content.

tal factors (Robertson and Holland, 2004). The results showed that oil content and oil yield were decreased in late planting dates but selenium treatment, as a supporting role, was able to reduce the adverse effects of end-season thermal stress in rapeseed cultivars.

\subsection{Oleic acid}

A significant difference was observed in the response of cultivars to year, planting date and selenium application in terms of oleic acid (Tab. 4). The highest oleic acid was observed in L72 cultivar with the average of $65.33 \%$ in normal planting date (Oct.7) and selenium application treatment but statistically non-significant with other cultivars (Tab. 4).

In rapeseed, oil quality is determined mainly by the amounts of oleic and linoleic fatty acids. Cooler temperatures at seed filling stage cause increase in oleic content of seeds (Pritchard et al., 2000; Fayyaz-Ul-Hassan et al., 2005). Similar to oil content and oil yield, higher amounts of oleic acid in the second year of the experiment can be attributed to lower mean temperature than the first year at seed filling period in critical months April and May (Tab. 1). Tohidi-Moghadam et al. (2011) reported that the amount of unsaturated fatty acids is reduced by drought stress in the development stage of seeds due to lower sink capacity. Safavi-Fard et al. (2018) reported that drought stress due to irrigation interruption in flowering and pod formation stages reduced oleic content of investigated canola cultivars. 
Selenium treatment reduce late-season thermal stress due to delayed planting date on oleic acid compared to the control treatment (Tab. 4). Selenium foliar application on canola plants in Hashem et al. (2013) study showed $107.7 \%$ increase in oleic acid content. In addition, in their study, selenium application reduced unfavorable impact of salt stress on canola plants.

\subsection{Linolenic acid}

A significant difference was observed in the response of cultivars to year, planting date and selenium application in terms of linolenic acid (Tab. 4). The interaction effect of planting date $\times$ selenium $\times$ cultivar revealed that delay in planting date and selenium application increased linolenic acid (Tab. 4). The highest linolenic acid was related to GKH0224 cultivar with the average of $7.36 \%$ in the late planting date (Oct. 27) and control treatment (Tab. 4).

According to the Safavi-Fard et al. (2018) study, drought stress and late planting date increased linolenic acid content of investigated canola cultivars, which was in agreement with the findings of present study. Aslam et al. (2009) reported that drought stress enhanced 1.7 to $2 \%$ in multiple unsaturated fatty acid contents such as linolenic and linoleic acids and 3.8\% reduce in oleic acid content. In addition, Hashem et al. (2013) reported that selenium application increase linolenic acid content of canola cultivars under salt stress, which was similar to present study.

\subsection{Linoleic acid}

Response of cultivars to year, planting date and selenium application was significant in terms of linoleic acid (Tab. 4). In normal planting date (Oct. 7) and selenium application, the highest amount of linoleic acid was related to L72 cultivar with the average of $20.63 \%$. Delay in planting date reduced the linoleic acid content of cultivars, while selenium application increased it (Tab. 4). Moreover, response of cultivars to selenium application in normal planting date was not statistically significant, while in delayed planting date, selenium application had a significant effect on cultivars. Therefore, the application of selenium treatment in delayed cultivation has more significant impact rather than its application in normal planting date. Similar result was reported by Hashem et al. (2013) for canola cultivars under salt stress. Result of present study was in accordance with the findings of Enjalbert et al. (2013) and Safavi-Fard et al. (2018) who found that drought stress reduced linoleic fatty acid content in rapeseed. TohidiMoghadam et al. (2011) study revealed that application of super absorbent polymer on canola genotypes under drought stress condition increased linoleic acid content for all genotypes from 18.91 to $19.69 \%$.

\subsection{Palmitic acid}

Response of cultivars to year, planting date and selenium application were significant in terms of palmitic acid (Tab. 4). L72 cultivar with the average of $5.79 \%$ in normal planting date (Oct.7) and selenium application had the highest amount of palmitic acid, while the highest amount of palmitic acid in semi-late planting date (Oct. 17) and delayed planting date (Oct.27) was related to Opera cultivar which was not statistically different with L72 cultivar (Tab. 4).

Delay in planting date reduced the palmitic acid content of cultivars, while selenium application increased it (Tab. 4). In addition, response of cultivars to selenium application in normal planting date (Oct.7) and semi-late planting date (Oct. 17) was not statistically significant, while in delayed planting date (Oct. 27), selenium application had a significant effect on cultivars. Therefore, the application of selenium treatment in delayed cultivation has more significant impact rather than its application in normal planting date.

Palmitic and stearic acids are two main saturated fatty acids in rapeseed. Shoja et al. (2018) reported that boron, zinc and sulfur treatment affected fatty acid composition of canola cultivars compared to the control. The least amount of saturated stearic and palmitic acids were observed with boron treatment. Bybordi and Mamedov (2010) found that foliar application of zinc and iron reduced saturated fatty acids and enhanced unsaturated fatty acids of canola. Result of present study was in consistence with the findings of Safavi-Fard et al. (2018) who found that drought stress reduced palmitic fatty acid content in canola, while Mekki et al. (1999) results in sunflower were opposite.

\subsection{Erucic acid}

Response of cultivars to planting date and selenium application was significant in terms of erucic acid (Tab. 4). L 72 cultivar with the average of $0.12 \%$ in normal planting date (Oct.7) and selenium application had the least amount of erucic acid (Tab. 4). Delay in planting date increased the erucic acid content of cultivars, while selenium application decreased it (Tab. 4). GKH0224 cultivar with the average of $0.49 \%$ in delayed planting date (Oct.27) and control treatment of selenium application had the highest erucic acid content (Tab. 4).

Erucic acid content of cultivars in all planting dates and was at standard level $(=<0.5 \%)$. This result was in consistent with the findings of Safavi-Fard et al. (2018) study in lateseason draught stress of canola cultivars. Fayyaz-Ul-Hassan et al. (2005) reported that erucic acid content of canola cultivars varied by different environments and varieties. In Shoja et al. (2018) study, boron + zinc treatment could significantly reduce erucic acid content of canola cultivars compared with the control. Results of present study was in accordance with the findings of Hashem et al. (2013) study who observed maximum reduce in erucic acid content of canola cultivars by using foliar application of selenium as compared with control treatment under salt stress.

\subsection{Glucosinolate content}

There was a significant difference in the reaction of cultivars to planting date and selenium application (Tab. 4). L72 cultivar with the average of $7.94 \mu$ mole/g in normal planting date (Oct.7) and selenium application had the least amount of glucosinolate content (Tab. 4), while the least 
amount of glucosinolate in semi-late planting date (Oct. 17) and delayed planting date (Oct.27) was related to Opera cultivar in both control and selenium application (Tab. 4). In addition, GKH0224 cultivar in late planting date (Oct. 27) in both control and selenium application with the average of 17.03 and $16.55 \mu \mathrm{mole} / \mathrm{g}$ had the highest glucosinolate content. Therefore, in normal and late planting dates, the glucosinolate content of all cultivars was at standard level which should be less than $30 \mu \mathrm{mole} / \mathrm{g}$ of dry weight of oil cake. Similar results were reported in Safavi-Fard et al. (2018) study. Champolivier and Merrien (1996) study revealed that glucosinolate accumulations in canola was affected by availability of water/moisture especially at seed filling stage. Fayyaz-Ul-Hassan et al. (2005) found that, although the impact of different locations on glucosinolate content of canola cultivars was non-significant but locally bred cultivars were better than those of foreign were. Tohidi-Moghadam et al. (2011) study showed that application of super absorbent polymer on canola genotypes under drought stress condition decreased about $7 \%$ of glucosinolate accumulations for all genotypes.

Quality of oil in oil seed rape and nutritional value of rapeseed oil cake depends on lower glucosinolate content, which is controlled by environmental and genetic factors (Salisbury et al., 1988). Fayyaz-Ul-Hassan et al. (2005) concluded that variety, soil moisture content and temperature are three main factors impact on the level of oil and canola fatty acid composition. Proper planting date and selection of suitable variety in any region can control those three main factors. Results of present study showed that selenium foliar application reduce glucosinolate accumulation of cultivars especially in late-season thermal stress.

\section{Conclusion}

Thermal stress, especially at the end of the season due to late planting date, is one of the important limiting factors in the growth and development of rapeseed. It can be concluded that late planting date influenced oil content, oil yield and fatty acid composition and glucosinolate content of rapeseed cultivars. Late-season thermal stress caused by late planting date reduced oil yield, oil content, oleic acid, linoleic acid, palmitic acid and increased linolenic acid, erucic acid and glucosinolate content of investigated cultivars. This study provided new important findings about the supportive and enhancer role of selenium in the form of sodium selenate on quantity and quality of oil in rapeseed plant. Selenium foliar application promote oil yield, oil content, oleic acid, linoleic acid, palmitic acid and decreased linolenic acid, erucic acid and glucosinolate content of investigated cultivars, in all planting date. In addition, selenium application was able to reduce the adverse effects of end-season thermal stress in rapeseed cultivars. The results of this study demonstrated that the highest amount of oil yield, oil content, oleic acid, linoleic acid, palmitic acid and the lowest amount of erucic acid and glucosinolate content were observed in L72 cultivar in both control and selenium application treatments. Present study intensifies the evidence for the effective role of selenium in crops.

Acknowledgements. The authors would like to thank Department of Oil Crops, Seed and Plant Improvement Institute,
Agricultural Research, Education and Extension Organization (AREEO), Iran for providing the facilities to conduct this research. The authors thank Assist. Prof. Dr. Hossein Zeinalzadeh-Tabrizi, Oil Crops Section, Crop and Horticultural Science Research Department, Ardabil Agricultural and Natural Resources Research and Education Center, AREEO, Ardabil, Iran for his valuable comments and statistical advice.

\section{References}

Aksouh N, Jacobs B, Stoddard F, Mailer R. 2001. Response of canola to different heat stresses. Aust J Agric Res 52(8): 817-824.

Aslam M, Nelson M, Kailis S, Bayliss K, Speijers J, Cowling W. 2009. Canola oil increases in polyunsaturated fatty acids and decreases in oleic acid in drought-stressed Mediterranean type environments. Plant Breed 128(4): 348-355.

Broadley MR, Alcock J, Alford J, et al. 2010. Selenium biofortification of high-yielding winter wheat (Triticum aestivum L.) by liquid or granular Se fertilisation. Plant Soil 332(1-2): 5-18.

Bybordi A, Mamedov G. 2010. Evaluation of application methods efficiency of zinc and iron for canola (Brassica napus L.). Not Sci Biol 2(1): 94-103.

Carvalho ISD, Miranda I, Pereira H. 2006. Evaluation of oil composition of some crops suitable for human nutrition. Ind Crop Prod 24(1): $75-78$.

Champolivier L, Merrien A. 1996. Effects of water stress applied at different growth stages to Brassica napus L. var. oleifera on yield, yield components and seed quality. Eur J Agron 5(3-4): 153-160.

Djanaguiraman M, Devi DD, Shanker AK, Sheeba JA, Bangarusamy U. 2005. Selenium-an antioxidative protectant in soybean during senescence. Plant Soil 272(1-2): 77-86.

Ducsay L, Lozek O. 2006. Effect of selenium foliar application on its content in winter wheat grain. Plant Soil Environ 52(2): 78.

Enjalbert J-N, Zheng S, Johnson JJ, Mullen JL, Byrne PF, Mckay JK. 2013. Brassicaceae germplasm diversity for agronomic and seed quality traits under drought stress. Ind Crop Prod 47: 176-185.

Fang Y, Wang L, Xin Z, Zhao L, An X, Hu Q. 2008. Effect of foliar application of zinc, selenium, and iron fertilizers on nutrients concentration and yield of rice grain in China. J Agric Food Chem 56(6): 2079-2084.

Fayyaz-Ul-Hassan HA, Cheema MA, Manaf A. 2005. Effects of environmental variation on oil content and fatty acid composition of canola cultivars. J Res (Sci) 16(2): 65-72.

Feng R, Wei C, Tu S. 2013. The roles of selenium in protecting plants against abiotic stresses. Environ Exp Bot 87: 58-68.

Germ M, Stibil V, Osvald J, Kreft I. 2007. Effect of selenium foliar application on chicory (Cichorium intybus L.). J Agric Food Chem 55(3): 795-798.

Gilbertson P, Johnson B, Berti M, Halvorson M. 2007. Seeding date and performance of specialty oilseeds in North Dakota. Issues in new crops and new uses. Alexandria: ASHS Press, pp. 105-110.

Gissel Nielsen G. 1981. Foliar application of selenite to barley plants low in selenium. Commun Soil Sci Plant Anal 12(6): 631-642.

Hartikainen H. 2005. Biogeochemistry of selenium and its impact on food chain quality and human health. $J$ Trace Elem Med Biol 18 (4): 309-318

Hartikainen H, Xue T, Pironen V. 2000. Selenium as an anti-oxidant and pro-oxidant in ryegrass. Plant Soil 225(1-2): 193-200.

Hashem HA, Hassanein RA, Bekheta MA, El-Kady FA. 2013. Protective role of selenium in canola (Brassica napus L.) plant subjected to salt stress. Egypt J Exp Biol (Bot) 9(2): 199-211. 
Hocking P, Stapper M. 2001. Effects of sowing time and nitrogen fertiliser on canola and wheat, and nitrogen fertiliser on Indian mustard. I. Dry matter production, grain yield, and yield components. Aust J Agric Res 52(6): 623-634.

$\mathrm{Hu}$ Q, Chen L, Xu J, Zhang Y, Pa G. 2002. Determination of selenium concentration in rice and the effect of foliar application of Seenriched fertiliser or sodium selenite on the selenium content of rice. J Sci Food Agric 82(8): 869-872.

$\mathrm{Hu}$ Q, Xu J, Pang G. 2003. Effect of selenium on the yield and quality of green tea leaves harvested in early spring. J Agric Food Chem 51(11): 3379-3381.

IRIMO. 2016. Iranian Meteorological Office Data Processing Center. Islamic Republic of Iran Meteorological Office.

ISO-5511:1992. 1998. Oilseeds-Determination of oil content-method using continuous-wave low-resolution nuclear magnetic resonance spectrometry (Rapid method). Geneva: International Organization for Standardization.

Izquierdo NG, Aguirrezábal LA, Andrade FH, Cantarero MG. 2006. Modeling the response of fatty acid composition to temperature in a traditional sunflower hybrid. Agron J 98(3): 451-461.

Kumar M. 2013. Crop plants and abiotic stresses. J Biomol Res Ther 3: e125.

Kutcher H, Warland J, Brandt S. 2010. Temperature and precipitation effects on canola yields in Saskatchewan, Canada. Agric For Meteorol 150(2): 161-165.

Lyons GH, Genc Y, Soole K, Stangoulis J, Liu F, Graham R. 2009. Selenium increases seed production in Brassica. Plant Soil 318 (1-2): 73-80.

Makkar H, Siddhuraju P, Becker K. 2007. A laboratory manual on quantification of plant secondary metabolites. Totowa, NJ, USA: Humana Press.

Mekki B, El-Kholi M, Mohamed E. 1999. Yield, oil and fatty acids contents as affected by water deficit and potassium fertilization in two sunflower cultivars. Egypt J Agron (Egypt) 21: 67-85.

Mora M, Durán P, Acuña J, Cartes P, Demanet R, Gianfreda L. 2015. Improving selenium status in plant nutrition and quality. $J$ Soil Sci Plant Nutr 15(2): 486-503.

Morrison MJ, Stewart DW. 2002. Heat stress during flowering in summer Brassica. Crop Sci 42(3): 797-803.

Nawaz F, Ahmad R, Ashraf M, Waraich E, Khan S. 2015. Effect of selenium foliar spray on physiological and biochemical processes and chemical constituents of wheat under drought stress. Ecotoxicol Environ Saf 113: 191-200.

Nelson LA, Grombacher A. 1992. G92-1076 Canola Production. Historical Materials from University of Nebraska-Lincoln Extension, $778 \mathrm{p}$.

Omidi H, Tahmasebi Z, Naghdi-Badi HA, Torabi H, Miransari M. 2010. Fatty acid composition of canola (Brassica napus L.), as affected by agronomical, genotypic and environmental parameters. C R Biol 333(3): 248-254.

Oz M. 2002. The effect of different sowing time on the yield and yield components in winter rapeseed varieties under Bursa Mustafakemalpasa conditions. J Fac Agric Uludag Univ (Turkey) 16: 1-13.

Ozer H. 2003. Sowing date and nitrogen rate effects on growth, yield and yield components of two summer rapeseed cultivars. Eur $J$ Agron 19(3): 453-463.

Pezzarossa B, Remorini D, Gentile ML, Massai R. 2012. Effects of foliar and fruit addition of sodium selenate on selenium accumulation and fruit quality. $J$ Sci Food Agric 92(4): 781-786.

Pilon-Smits EA, Quinn CF, Tapken W, Malagoli M, Schiavon M. 2009. Physiological functions of beneficial elements. Curr Opin Plant Biol 12(3): 267-274.
Poggi V, Arcioni A, Filippini P, Pifferi PG. 2000. Foliar application of selenite and selenate to potato (Solanum tuberosum): Effect of a ligand agent on selenium content of tubers. J Agric Food Chem 48 (10): 4749-4751.

Pritchard F, Eagles H, Norton R, Salisbury P, Nicolas M. 2000. Environmental effects on seed composition of Victorian canola. Aust $J$ Exp Agric 40(5): 679-685.

Robertson M, Holland J. 2004. Production risk of canola in the semi-arid subtropics of Australia. Aust J Agric Res 55(5): 525-538.

Safavi-Fard N, Heidari-Sharifabad H, Shirani-Rad AH, MajidiHeravan E, Daneshian J. 2018. Effect of drought stress on qualitative characteristics of canola cultivars in winter cultivation. Ind Crop Prod 114: 87-92.

Saidi I, Chtourou Y, Djebali W. 2014. Selenium alleviates cadmium toxicity by preventing oxidative stress in sunflower (Helianthus annuus L.) seedlings. J Plant Physiol 171(5): 85-91.

Sajedi NA, Ardakani MR, Madani H, Naderi A, Miransari M. 2011. The effects of selenium and other micronutrients on the antioxidant activities and yield of corn (Zea mays L.) under drought stress. Physiol Mol Biol Plant 17(3): 215-222.

Salisbury P, Sang J, Cawood R. 1988. Genetic and environmental factors influencing glucosinolate content in rapeseed in Southern Australia. Paper presented at the 7th International Rapeseed Congress/ convened under the patronage of Stanislaw Zieba; by the Plant Breeding and Acclimatization Institute under the auspices of the Group Consultatif International de Recherche sur le Colza.

SAS. 2008. SAS/STAT User's Guide Version 9.1. Cary, NC: SAS Institute.

Schwarz K, Foltz CM. 1957. Selenium as an integral part of factor 3 against dietary necrotic liver degeneration. J Am Chem Soc 79 (12): 3292-3293.

Seppänen M, Turakainen M, Hartikainen H. 2003. Selenium effects on oxidative stress in potato. Plant Sci 165(2): 311-319.

Seppänen MM, Kontturi J, Heras IL, Madrid Y, Cámara C, Hartikainen H. 2010. Agronomic biofortification of Brassica with selenium-enrichment of SeMet and its identification in Brassica seeds and meal. Plant Soil 337(1-2): 273-283.

Shah SA, Rahman K. 2009. Yield and growth response of rapeseed (Brassica napus L.) mutants to different seeding rates and sowing dates. Pak J Bot 41(6): 2711-2716.

Shirani-Rad A, Shahsavari N, Jais H, Dadrasnia A, Askari A, Saltughi M. 2015a. Fall cultivar of rapeseed (Brassica napus L.) for reduction of damage due to late season drought. Indian J Agric Sci 85(1): 50-54.

Shirani-Rad AH, Bitarafan Z, Rahmani F, Taherkhani T, MoradiAghdam A, Nasresfahani S. 2015b. Effects of planting date on spring rapeseed (Brassica napus L.) cultivars under different irrigation regimes. Turk J Field Crop 19(2): 153-157.

Shoja T, Majidian M, Rabiee M. 2018. Effects of zinc, boron and sulfur on grain yield, activity of some antioxidant enzymes and fatty acid composition of rapeseed (Brassica napus L.). Acta Agric Slov 111(1): 73-84.

Sinaki JM, Majidi-Heravan E, Shirani-Rad AH, Noormohammadi G, Zarei G. 2007. The effects of water deficit during growth stages of canola (Brassica napus L.). Am-Eur J Agric Environ Sci 2(4): 417-422.

Singh M, Singh N, Bhandari D. 1980. Interaction of selenium and sulfur on the growth and chemical composition of Raya. Soil Sci 129(4): 238-244.

Singh AK, Singh H, Rai O, Singh G, Prakash V, Singh NPS, Singh R. 2017. Effect of sowing dates and varieties for higher productivity 
of Indian mustard (Brassica juncea L.). J Appl Nat Sci 9(2): 883-887.

Soleymani A, Moradi M, Naranjani L. 2011. Effects of the irrigation cut-off time in different growth stages on grain and oil yield components of autumn's canola cultivars in Isfahan region. $J$ Water Soil Sci 25(3): 426-435.

Stephen R, Saville D, Watkinson J. 1989. The effects of sodium selenate applications on growth and selenium concentration in wheat. N Z J Crop Hortic Sci 17(3): 229-237.

Tohidi-Moghadam HR, Zahedi H, Ghooshchi F. 2011. Oil quality of canola cultivars in response to water stress and super absorbent polymer application. Pesqui Agropecu Trop 41(4): 579-586.

Turakainen M, Hartikainen H, Ekholm P, Seppänen MM. 2006. Distribution of selenium in different biochemical fractions and raw darkening degree of potato (Solanum tuberosum L.) tubers supplemented with selenate. J Agric Food Chem 54(22): 8617-8622.
Uzun B, Furat S. 2009. Sowing date effects on growth, flowering, oil content and seed yield of canola cultivars. Asian J Chem 21(3): 1957.

Xue T, Hartikainen H, Piironen V. 2001. Antioxidative and growthpromoting effect of selenium on senescing lettuce. Plant Soil 237 (1): 55-61.

Yang F, Chen L, Hu Q, Pan G. 2003. Effect of the application of selenium on selenium content of soybean and its products. Biol Trace Elem Res 93(1-3): 249-256.

Yao X, Jianzhou C, Xueli H, Binbin L, Jingmin L, Zhaowei Y. 2013. Effects of selenium on agronomical characters of winter wheat exposed to enhanced ultraviolet-B. Ecotoxicol Environ Saf 92 : $320-326$.

Ylaranta T. 1983. Effect of applied selenite and selenate on the selenium content of barley (Hordeum vulgare L.). Ann Agric Fenn 22: $164-174$.

Cite this article as: Davoudi A, Mirshekari B, Shiranirad A, Farahvash F, Rashidi V. 2019. Effect of selenium foliar application on oil yield, fatty acid composition and glucosinolate content of rapeseed cultivars under late-season thermal stress. OCL 26: 43. 